\title{
A Preliminary Study on Reducing the Dosage of Chemical Fertiliser by using Empty Fruit Bunch as Soil Amendment on the Growth of Choy Sum
}

\author{
J.L. Tan*, K.Y. Ang, M.H. Chow, E.T.Y. Lee, K.H. Lee, L.Y. Lee, S.W. Ooi, \\ W.C. Soh and R. Sithambaram \\ Department of Agricultural and Food Science, Faculty of Science, Universiti Tunku Abdul \\ Rahman, Perak, Malaysia
}

\begin{abstract}
Palm oil production results in many valuable products, but it also generates agricultural wastes such as empty fruit bunch (EFB). EFB composting usually produces nutrient-enriched bio-fertilisers and thus, able to help in reducing the chemical fertilisers applied. Most conventional vegetable farmers in Malaysia solely depend on chemical fertilisers in crop production. However, the intensive use of chemical fertilisers has led to various side effects. Thus, this study was to determine the effect on the growth of choy sum by reducing the dosage of chemical fertiliser with EFB compost as soil amendments. Randomized Complete Block Design (RCBD) methods were used in this study. The fresh weight, dry weight and plant height of the choy sum were found to be not significantly different among all the treatments $\left(\mathrm{T}_{1}-\mathrm{T}_{4}\right)$ and positive control. This study found that $\mathrm{T}_{4}$ with $30 \%$ lesser chemical fertiliser applied showed no significant growth difference with the rest of the treatments indicating that EFB may have the ability to help in reducing chemical fertiliser usage in the growth of choy sum. Further study is recommended as this will help in better EFB waste management and lowering the cost of production for local vegetables.
\end{abstract}

Keywords: chemical fertiliser reduction; empty fruit bunches; soil amendments; vegetables

\section{INTRODUCTION}

Oil palm (Elaeis guineensis) is one of the oil-producing crops grown in the world. Among the oil crops such as soybean, rapeseed, sunflower and peanut, oil palm has the highest yield of oil-based hydrocarbons (Murphy, 2014). Malaysia and Indonesia are the major palm oil producers, producing up to $85 \%$ of the world's palm oil (Alam et al., 2015). Palm oil production results in many valuable products. Still, it also generates agricultural wastes such as empty fruit bunch (EFB), oil palm fronds, palm oil mill effluent (POME), palm mesocarp fibre and palm kernel shell (PKS) (Abdulrazik et al., 2017). According to Abas et al. (2011), approximately 19.3 million tonnes (23\%) of EFB biomass is produced from a total of 83.9 million tonnes of fresh fruit bunch (FFB). Being abundant as an agriculture waste from palm oil production,
EFB is used for many purposes, such as feedstock to produce renewable energy (Abas et al., 2011). In recent years, many oil palm mills in Malaysia are active in composting EFB and POME for better waste management practice (Then et al., 2016). EFB composting usually produces nutrient-enriched bio-fertilisers, and thus, able to help in reducing the chemical fertilisers applied (Siddiquee et al., 2017). Then et al. (2016) found that EFB compost also acts as carriers for nitrogenfixing bacteria and phosphate solubilizing bacteria. Therefore, the possibility of incorporating these bacteria into EFB bio-fertilisers will help in providing more readily available nitrogen and phosphate nutrients for the plants. According to Gandahi and Hanafi (2014) and Chan et al. (2019), EFB as soil amendment do not provide sufficient nutrient for plant growth. Still, it helps to retain more soil 
moisture, thus providing favourable condition for soil microfauna.

Since the green revolution, most conventional vegetable farmers in Malaysia solely depend on chemical fertilisers in crop production. In 2014, the total N, P and K fertilisers consumed in Malaysia was 1.97 million tonnes (Food and Agriculture Organization, 2019). The main nitrogen fertilisers are urea, ammonium sulphate and ammonium nitrate, while the main phosphorus fertilisers are rock phosphate, ammonium phosphate and superphosphate. Potassium chloride is the major potassium fertilisers, and potassium sulphate is another alternative (Zakaria, 2006). According to Chan et al. (2019), the use of chemical fertilisers has increased significantly to meet the increasing demand for crops. However, the intensive use of chemical fertilisers has led to various side effects, namely water and soil pollution. Water pollution usually happens through leaching of fertilisers into the nearby water body causing problems such as eutrophication. In the long run, chemical fertilisers will lead to soil problems such as soil fertility deterioration, soil structure deterioration and decrease in soil pH (Savci, 2012). Such practices will lead to unsustainable agriculture, and in future may not produce a good yield. Addition of organic matter as a soil amendment is one of the ways in soil restoration. Organic matter content includes plant, animal and microbial residues can help in sustaining soil fertility and improve the soil physical, chemical and biological properties (Diacono \& Montemurro, 2010). This study was conducted to determine the effect on the growth of choy sum by reducing the dosage of chemical fertiliser with oil palm EFB compost as soil amendments.

\section{MATERIALS AND METHOD}

\section{A. Experimental Site}

This study was carried out in the Agricultural Park (N $4^{\circ}$ 20'31.02072", E 101 ' 8'24.5454") of Universiti Tunku Abdul Rahman, Kampar Campus in Kampar, Perak, Malaysia from February 2019 to May 2019. The altitude of the Agriculture Park is $118.49 \mathrm{~m}$ above sea level. The mean temperature in Kampar area is $27.3^{\circ} \mathrm{C}$, and the average annual rainfall is 3133 mm (Merkel, 2015).

\section{B. Preparation of Compost Empty Fruit Bunches (EFB)}

The EFB were piled and turned daily to encourage aeration. Water was added whenever necessary for microbial growth and activity. The compost was ready in approximately 3 months (90 days).

\section{Experimental Design}

Eighteen planting beds with a size of $0.6 \mathrm{~m}^{2}$ were layout in Randomized Complete Block Design (RCBD) with three replications for each treatment (Figure 1) (Yeshiwas et al., 2018). There were four treatments and two controls. The negative control was without any input of nutrients, while the positive control was applied with only compound fertiliser (NPK: 15-15-15). EFB was applied as a soil amendment to the four treatments at the rate of $1500 \mathrm{~kg} / 4046 \mathrm{~m}^{2}$ before sowing. The application rate follows the local farmers' application rate for other soil amendments. The four treatments were applied with 100\% chemical fertiliser, 90\% chemical fertiliser, $80 \%$ chemical fertiliser and $70 \%$ chemical fertiliser, respectively. The $100 \%$ chemical fertiliser application rate was $62.5 \mathrm{~kg} / 4046 \mathrm{~m}^{2}$. This is the average application rate of chemical fertiliser of the local farmers. The first application of chemical fertiliser was done 7 days after sowing, and the following application was done every 7 days. Broadcasting was used when applying the fertiliser to the plots (Figure 1).

\begin{tabular}{|l|c|c|c|c|c|c|}
\hline Blocks & \multicolumn{7}{|c|}{ Treatments } \\
\hline 1 & T1 & +ve control & T2 & T4 & -ve control & T3 \\
\hline 2 & -ve control & T3 & T1 & +ve control & T4 & T2 \\
\hline 3 & T2 & T4 & -ve control & T3 & T1 & +ve control \\
\hline
\end{tabular}

Note: -ve control: no input; +ve control: chemical fertiliser only; T1: 100\% chemical fertiliser with EFB; T2: 90\% chemical fertiliser with EFB; T3: 80\% chemical fertiliser with EFB; T4: 70\% chemical fertiliser with EFB.

Figure 1. The layout of the treatments in a randomised complete block design (RCBD) 


\section{Planting}

Commercial choy sum seeds (Brassica chinensis L. var. parachinensis, Leckat, 008 Wang Bujang, China) were purchased from a local agricultural shop. Direct seeding was used to avoid transplanting shock (Masarirambi et al., 2012). Each treatment plot was sowed with approximately $15 \mathrm{~g}$ of seeds (approximately 500 seeds/g) using a broadcasting technique. Seeds were mixed with sand before broadcasted to obtain uniform seed distribution (Masarirambi et al., 2012). Seedlings were thinned 14 days after sowing to allow spacing between plants for growth. Overhead water sprinklers were used for irrigation. Weeds were controlled by hand weeding when necessary.

\section{E. Data Collection}

The fresh weight, dry weight, plant height and root length were measured to assess the response of choy sum to all the treatments. Twenty plants from each plot were sampled randomly to obtain the average of the measurements. The sampling of the plants for growth analysis was carried out after 30 days of planting. The fresh weight was measured immediately using a portable electronic balance (Camry, EIo2HS, China). The plant height and root length were measured using the Auora ${ }^{\circledR}$ plastic ruler. The plant samples were put into a drying oven (Memmert, MMT-IN110, Germany) at $40^{\circ} \mathrm{C}$ for $48 \mathrm{~h}$ before measuring the dry weight using an electronic laboratory balance (Mettler Toledo, ME1002, Switzerland).

IBM Statistical Package for the Social Sciences (SPSS) version 23.0 was used in the analysis of the data. The collected data were subjected to one-way analysis of variance (ANOVA) and posthoc test, namely Tukey HSD. Before the ANOVA, the assumption of normality was evaluated using Shapiro-Wilks (S-W) W tests. If the assumption of normality was violated $(\mathrm{p}<0.05)$, the Kruskal-Wallis H-test was used as an alternative to one-way ANOVA. The Mann-Whitney Utest was used as a post-doc test for the Kruskal-Wallis $\mathrm{H}$ test (Tan, 2012).

\section{RESULTS AND DISCUSSION}

The assumption of normality for fresh weight, dry weight, plant height and root length were evaluated using the Shapiro-Wilk (S-W) W test. All the comparison made did not violate the assumption of normality ( $p>0.05$ ), except for the root length. Therefore, one-way ANOVA was used to test the significant difference $(\mathrm{P}<0.05)$ for fresh weight, dry weight and plant height. The Kruskal-Wallis H-test was used to test the significant difference $(\mathrm{p}<0.05)$ for the root length. The results of one-way ANOVA show a significant difference in the fresh weight, dry weight and plant height. The KruskalWallis H-test also show a significant difference in the root length. Referring to the Tukey HSD test, the only significant difference in the fresh weight, dry weight and plant height are between the rest of treatments versus negative control (Table 1). There is no significant difference in the fresh weight, dry weight and plant height between the different treatments and positive control. The Mann-Whitney U-test was carried out as the non-parametric alternative to the Tukey HSD test for the root length (Table 1). A significant difference in root length was observed between negative control and the rest of the treatments, except for T2. Root length in T1 is significantly longer than the positive control, while no significant difference with $\mathrm{T}_{2}, \mathrm{~T}_{3}$ and $\mathrm{T}_{4}$. Root length of $\mathrm{T}_{2}, \mathrm{~T}_{3}$ and $\mathrm{T}_{4}$ is found to be not significantly different that of positive control.

All the treatments and positive control have significantly better growth compared to negative control which indicates that the fertilisers applied had a positive effect on the growth of choy sum (Table 1). There were no significant effects observed in the fresh weight, dry weight and plant height between the positive control (without EFB soil amendments) and $\mathrm{T} 1$ (normal chemical fertiliser application rate) with EFB soil amendments indicating that the EFB as soil amendments might not help in providing more nutrients for significantly better growth. According to Table 1, the mean fresh weight and dry weight of positive control are slightly higher than $\mathrm{T} 1$, whereas the plant height of $\mathrm{T} 1$ is slightly higher, and the root length is significantly higher. All the treatments with EFB, even with less chemical fertilisers have longer root lengths. This is probably because EFB as a compost provides high porosity, water holding capacity and also high nutrient holding capacity (Gandahi \& Hanafi, 2014). The elongation 
of roots may be limited by soil properties, namely soil strength and compaction (Bengough et al., 2006). The addition of EFB to the soil as soil amendments may result in better soil properties, thus, resulting in better root growth. According to Liew et al. (2010), application of EFB compost has a positive effect on the development of roots for oil palm, thus resulting in better nutrient uptake. Based on the results, choy sum grown with $30 \%$ lesser chemical fertilisers with EFB soil amendments (T4) resulted in similar fresh weight, dry weight, plant height and root length as compared to positive control and T1. This may be attributed to better root growth which helps the plant to absorb the nutrients provided more efficiently. EFB may not be providing high nutrients, averagely $0.57 \% \mathrm{~N}, 0.084 \% \mathrm{P}$ and $2.252 \% \mathrm{~K}$, but it contains other organic matter that can improve the soil properties (Gandahi \& Hanafi, 2014). This will encourage the growth of beneficial microbes in the soil, such as nutrient solubilizing bacteria (Then et al., 2016), thus resulting in better soil microfauna, which will improve plant growth.

The EFB as a soil amendment may not provide sufficient additional nutrients for significant growth, but in this study, it did affect the growth of choy sum. The fresh and dry weight of $\mathrm{T}_{4}$ treated with $30 \%$ lesser chemical fertilisers were not significantly different from the choy sum grown without reduction of fertilisers. This is a good indication that the EFB may help in better nutrient uptake, thus resulting in better utilization of fertilisers and lesser leaching. Although the mean weight (fresh and dry) were the lowest compared to the rest of the treatments provided with fertilisers, the mean plant height of $\mathrm{T}_{4}$ is the tallest among the treatments. This indicates that even with lesser fertilisers, the choy sum in $\mathrm{T}_{4}$ can achieve comparable height and weight. This, however, can be attributed to either EFB as a soil amendment can produce similar growth or the dosage of fertilisers used by local farmers are too high or both. The findings of Wahi and Yusup (2016) show that EFB compost used in the growth of radish (Raphanus sativus L.) resulted in better root and leaf growth as well as better germination index. In addition, Rosenani et al. (2016) reported that applying EFB compost in the growth medium improved the growth and development of oil palm seedlings as well as the nutrient uptake of the plants. With this evidence, adding EFB as soil amendment seems to be beneficial and can improve growth by improving the soil properties and increasing nutrient uptake. However, the content of the EFB compost should be analysed and better comparison on the reduction of fertilisers with EFB as soil amendment should be carried out to gain better insight of the effect on the growth of choy sum.

Table 1. The mean of the measured parameters of the choy sum sampling

\begin{tabular}{|c|c|c|c|c|}
\hline & Fresh Weight (g) & Dry Weight (g) & Plant Height (cm) & Root Length $(\mathrm{cm})$ \\
\hline Negative control & $44.10 \pm 25.93^{a}$ & $7 \cdot 32 \pm 3.38^{a}$ & $5 \cdot 38 \pm 1.97^{\mathrm{a}}$ & $4.07 \pm 1.15^{\mathrm{a}}$ \\
\hline Positive control & $329.57 \pm 141.17^{b}$ & $35.23 \pm 10.6 o^{b}$ & $10.50 \pm 1.53^{b}$ & $5.78 \pm 0.94^{b}$ \\
\hline $\mathrm{T} 1$ & $294.70 \pm 96.37^{b}$ & $31.99 \pm 7.38^{b}$ & $10.71 \pm 1.87^{b}$ & $7.42 \pm 1.45^{c}$ \\
\hline $\mathrm{T} 2$ & $300.20 \pm 94.22^{b}$ & $29.07 \pm 7.83^{b}$ & $12.28 \pm 1.94^{b}$ & $6.40 \pm 2.52^{a b c}$ \\
\hline $\mathrm{T} 3$ & $272.70 \pm 130.96^{b}$ & $29.27 \pm 10.91^{b}$ & $11.19 \pm 3.64^{b}$ & $6.13 \pm 1.58 \mathrm{bc}$ \\
\hline $\mathrm{T}_{4}$ & $261.55^{ \pm 77.46^{b}}$ & $28.79 \pm 6.11^{b}$ & $12.47 \pm 2.31^{\mathrm{b}}$ & $6.00 \pm 1.36^{b c}$ \\
\hline
\end{tabular}

Note: negative control: no input; positive control: chemical fertiliser only; T1: 100\% chemical fertiliser with EFB; T2: 90\% chemical fertiliser with EFB; T3: 80\% chemical fertiliser with EFB; T4: 70\% chemical fertiliser with EFB. The different superscript alphabets indicate a significant difference in Tukey HSD and Mann-Whitney $U$-test within the column.

\section{CONCLUSION}

There was no significant difference in the fresh weight, dry weight and plant height between all the treatments and the positive control. $\mathrm{T} 4$ with $30 \%$ lesser chemical fertiliser applied showed no significant growth difference with the rest of the treatments with a higher dosage of chemical fertiliser, thus indicating that EFB may have the ability to help in reducing chemical fertiliser usage in the cultivation of choy sum. This result served as baseline data for further study into the effect on the growth of choy sum with reduced chemical fertilisers and EFB as a soil amendment. This would help the oil palm industry in better waste management and also help the local vegetable farmers to lower their cost of production with lesser input of chemical fertilisers. 


\section{ACKNOWLEDGEMENT}

Authors acknowledge the support from the Faculty of Science, Universiti Tunku Abdul Rahman, Malaysia. This project was supported by the Department of Agricultural and Food Science, Faculty of Science, Universiti Tunku Abdul Rahman, Malaysia.

\section{REFERENCES}

Abas, R, Kamarudin, MF, Nordin, ABA \& Simeh, MA 2011, 'A study on the Malaysian oil palm biomass sector - supply and perception of palm oil millers', Oil Palm Industry Economic Journal, vol. 11, no. 1, pp. 28-41.

Abdulrazik, A, Elsholkami, M, Elkamel, A \& Simon, L 2017, 'Multi-products productions from Malaysian oil palm empty fruit bunch (EFB): Analyzing economic potentials from the optimal biomass supply chain', Journal of Cleaner Production, vol. 168, pp. 131-148.

Alam, ASAF, Er, AC \& Begum, H 2015, 'Malaysian oil palm industry: Prospect and problem', Journal of Food, Agriculture \& Environment, vol. 13, no. 2, pp. 143-148.

Bengough, AG, Bransby, MF, Hans, J, McKenna, SJ, Roberts, TJ \& Valentine, TA 2006, 'Root responses to soil physical conditions; growth dynamics from field to cell', Journal of Experimental Botany, vol. 57, no. 2, pp. 437-447.

Chan, MKY, Tahashshunan Mujaddid, BA \& Nurmaliena, BR 2019, 'Effect of amended soil with oil palm empty fruit bunch compost on the $\mathrm{pH}$ of soil and the growth of choy sam (Brassica chinensis var parachinensis)', Journal of Engineering and Applied Sciences, vol. 14, no. 3, pp. 60576061.

Diacono, M \& Montemurro, F 2010, 'Long-term effects of organic amendments on soil fertility. A review ', Agronomy for Sustainable Development, vol. 30, pp. 401-422.

Food and Agriculture Organization 2019. FAOSTAT, viewed 27 February 2020, $<$ www.fao.org/faostat/en/\#country/131>.

Gandahi, AW \& Hanafi, MM 2014, Bio-composting oil palm waste for improvement of soil fertility, ed DK Maheshwari, in Composting for Sustainable Agriculture, Springer International Publishing, Switzerland, pp. 209-243.
Liew, VK, Rahman, ZA, Musa, MH \& Hussein, A 2010, 'Nutrient absorption by oil palm primary roots as affected by empty fruit bunch application', Journal of Oil Palm Research, vol. 22, pp. 711-720.

Masarirambi, M, Sibandze, N, Wahome, PK \& Oseni, T 2012, 'Effects of kraal manure application rates on growth and yield of wild okra (Corchorus olitorius L.) in a sub-tropical environment', Asian Journal of Agricultural Science, vol. 4, no. 1, pp. 89-95.

Merkel, A 2015. Kampar Climate, Climate-Data.org, viewed 10 July 2019 ,

$<$ https://en.climate-

data.org/asia/malaysia/perak/kampar-25987/>.

Murphy, DJ 2014, 'The future of oil palm as a major global crop: opportunities and challenges', Journal of Oil Palm Research, vol. 26, no. 1, pp. 1-24.

Rosenani, AB, Rovica, R, Cheah, PM \& Lim, CT 2016, 'Growth performance and nutrient uptake of oil palm seedling in prenursery stage as influenced by oil palm waste compost in growing media', International Journal of Agronomy, vol. 2016, pp. 1-8.

Savci, S 2012, 'An agricultural pollutant: chemical fertilizer', International Journal of Environmental Science and Development, vol. 3, no. 1, pp. 77-80.

Siddiquee, S, Shafawati, SN \& Naher, L 2017, 'Effective composting of empty fruit bunches using potential Trichoderma strains', Biotechnology Reports, vol. 13, pp. 17.

Tan, JL 2012, 'Biodiversity of shrimps in ex-tin mining ponds around Kampar, Perak', Bachelor Thesis, Universiti Tunku Abdul Rahman, Perak, Malaysia. 
Then, KH, Sarmidi, MR, Alwee, SSRS \& Zakaria, ZA 2016, 'Recycling of oil palm empty fruit bunch as potential carrier for biofertilizer formulation', Jurnal Teknologi, vol. 78, no. 2, pp. 165-170.

Wahi, R \& Yusup, IA 2016, 'Empty fruit bunches compost and germintation of Raphanus sativs L.', Borneo Journal of Resource Science and Technology, vol. 6, no. 1, pp. 10-18.

Yeshiwas, Y, Zewdie, BYB, Chekol, A \& Walle, A 2018, 'Effect of nitrogen fertilizer and farmyard manure on growth and yield of lettuce (Lactuca sativa L.)', International Journal of Agricultural Research, vol. 13, pp. 74-79.

Zakaria, A 2006, 'Soil-enhancing technologies for improving crop productivity in Malaysia and considerations for their use', in International Workshop on Sustained Management of the Soil-Rhizosphere System for Efficient Crop Production and Fertilizer Use, 16-20 October 2006, Food and Fertilizer Technology Center (FFTC), Bangkok, Thailand. 